\title{
"Exploring organizational culture at a state-owned enterprise in South Africa: a process approach"
}

\begin{tabular}{|c|c|}
\hline & Patrick J. Lekgothoane (D http://orcid.org/0000-0002-2109-2384 \\
\hline AUTHORS & Molefe Jonathan Maleka id http://orcid.org/0000-0003-1929-8532 \\
\hline & Zeleke Worku (D https://orcid.org/0000-0002-8808-3052 \\
\hline ARTICLE INFO & $\begin{array}{l}\text { Patrick J. Lekgothoane, Molefe Jonathan Maleka and Zeleke Worku (2020). } \\
\text { Exploring organizational culture at a state-owned enterprise in South Africa: a } \\
\text { process approach. Problems and Perspectives in Management, 18(2), 431-440. } \\
\text { doi:10.21511/ppm.18(2).2020.35 }\end{array}$ \\
\hline DOI & http://dx.doi.org/10.21511/ppm.18(2).2020.35 \\
\hline RELEASED ON & Friday, 03 July 2020 \\
\hline RECEIVED ON & Wednesday, 20 May 2020 \\
\hline ACCEPTED ON & Friday, 29 May 2020 \\
\hline & $(\mathrm{cc}) \mathrm{EY}$ \\
\hline LICENSE & $\begin{array}{l}\text { This work is licensed under a Creative Commons Attribution } 4.0 \text { International } \\
\text { License }\end{array}$ \\
\hline JOURNAL & "Problems and Perspectives in Management" \\
\hline SSN PRINT & $1727-7051$ \\
\hline SSN ONLINE & $1810-5467$ \\
\hline PUBLISHER & LLC "Consulting Publishing Company "Business Perspectives" \\
\hline FOUNDER & LLC "Consulting Publishing Company "Business Perspectives" \\
\hline
\end{tabular}

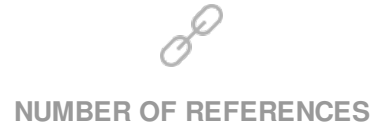

71

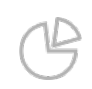

NUMBER OF FIGURES

0
=:-:

NUMBER OF TABLES

2

(C) The author(s) 2022. This publication is an open access article. 


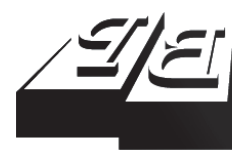

BUSINESS PERSPECTIVES

○

LLC "CPC "Business Perspectives" Hryhorii Skovoroda lane, 10, Sumy, 40022, Ukraine www.businessperspectives.org

Received on: $20^{\text {th }}$ of May, 2019 Accepted on: $2^{\text {th }}$ of May, 2020 Published on: $3^{\text {rd }}$ of July, 2020

(c) Patrick J. Lekgothoane, Molefe Jonathan Maleka, Zeleke Worku, 2020

Patrick J. Lekgothoane, Doctor, Lecturer, Department of People Management and Development, Faculty of Management Science, Tshwane University of Technology, South Africa.

Molefe Jonathan Maleka, Doctor, Senior Lecturer, Department of People Management and Development, Faculty of Management Science, Tshwane University of Technology, South Africa. (Corresponding author)

Zeleke Worku, Ph.D., Professor Business School, Tshwane University of Technology, South Africa.

Patrick J. Lekgothoane (South Africa), Molefe Jonathan Maleka (South Africa), Zeleke Worku (South Africa)

\title{
EXPLORING ORGANIZATIONAL CULTURE AT A STATE-OWNED ENTERPRISE IN SOUTH AFRICA: A PROCESS APPROACH
}

\begin{abstract}
The researchers intended to explore organizational culture at a state-owned enterprise (SOE) in South Africa. The reviewed literature showed very few similar studies where job satisfaction was tested as a mediator between organizational citizenship behavior and organizational culture. Furthermore, the reviewed literature revealed that Martins' organizational culture model, which was used to give theoretical grounding to the study, did not have job satisfaction as a mediator. The research design was exploratory, correlational, and cross-sectional. A total of 204 respondents were selected using a stratified sampling technique. The major finding was that the respondents perceived the organizational culture as a hostile, bellicose culture, rife with politics. The unexpected result was a significant positive relationship between organizational citizenship behavior and organizational culture. This means that even when the organization's culture was hostile, employees did not abuse and leave and went beyond the call of duty. It was found that job satisfaction did not mediate the relationship between organizational citizenship behavior and organizational culture.
\end{abstract}

Keywords

JEL Classification

\section{INTRODUCTION}

Organizational culture is a construct of interest to organizational psychology (Naidoo \& Martins, 2014) and management sciences scholars (Demir, 2015). It can adversely or positively affect the implementation of the organization strategy. Drucker opines that "culture eats strategy for breakfast" (as cited in Teasdale, 2002, p. 195). It can adversely affect any organization's performance (Kamaamia, 2017), including stateowned enterprises (Chavunduka, Fauzi, Muranda, Sifile, Mabvure, \& Dandira, 2014). Internationally, particularly in Greece, it was found that, at a public enterprise with a hostile culture, there was a great deal of politics, jealousy, and negative emotions, there was high attrition of skilled workers, and junior employees were sexually harassed and bullied by managers (Rovithis, Liardakis, Merkouris, Patiraki, Nassilaki, \& Philithis, 2017).

A culture with a hostile relationship instead of cooperation is known as bureaucratic (Raaphorst, 2017). A study at a Chinese state-owned enterprise (SOE) showed that, where there was no trust or affective commitment, employees were more likely to resign, and their organizational citizenship was adversely affected (Wong, 2017). Conversely, at an SOE in India, the data showed that a positive organizational culture enhanced job satisfaction and affective commitment (Saha \& Kumar, 2018). Besides, the studies found that, where a positive culture 
existed, employees shared information (Tseng, 2017), and managers treated employees with respect and dignity (Saks \& Gruman, 2011).

It can be deduced that there are two types of organizational cultures: positive, and bellicose or hostile. A hostile culture is perpetuated by organizational politics and hostility (O'Donnell \& Boyle, 2008), while a positive culture is about helping others and employees (Confeld, 2016). In some instances, it has been found that a culture of nepotism during recruitment and selection is rife (Mahlangu, 2001, p. 46), where employees with appropriate qualifications and experience are overlooked and not appointed in critical and managerial positions (Spector, 1985).

Based on the above discussion, it is clear that both individual (i.e., job satisfaction and organizational citizenship behavior) and organizational (i.e., recruitment and selection) factors predict organizational culture. Previous research has shown that in South Africa, a hostile or bellicose culture prevails in SOEs (Maleka \& Rankhumise, 2014). In such an organizational culture, employees are bullied during performance appraisals, and those who object are given poor performance appraisals and do not receive career development opportunities (Maleka, 2012). Furthermore, there is evidence that employees do not go beyond the call of duty in South African SOEs, meaning that a lack of organizational citizenship behavior is rife (Garg \& Ramjee, 2013). It was against this background that the researchers embarked on this study to quantify the predictors of a culture of respect or a hostile culture.

Thus, the study aimed to explore organizational culture at the SOE. This was achieved by measuring how respondents rated the organization culture and its predictors, i.e., organizational citizenship behavior and job satisfaction. In the next section, the literature to determine the direct relationship between organizational citizenship behavior and organizational culture is reviewed. Besides, the discussion is on how job satisfaction mediates the relationship between organizational citizenship behavior and organizational culture. The hypotheses are developed.

\section{LITERATURE REVIEW AND HYPOTHESES DEVELOPMENT}

Scholars internationally have developed organizational culture theoretical frameworks (Fleury, 2009). Like in this study, they have used individual and organizational factors to develop their frameworks (Ankrah, Proverbs, \& Debrah, 2009). Organizational predictors that have been measured by scholars are innovation and risk-taking, attention to detail, outcome orientation, people communication, training and development, rewards, decision making, planning, teamwork, management practices, work play, processes, collaboration, control, cultivation, competence, clan culture, adhocracy, and market (Harrison, 1972; A. Ramdhan, M. A. Ramdhan, \& Ainisyifa, 2017). However, there seems to be a lack of studies focusing on organizational citizenship behavior as a predictor of organizational culture. Hence, the researchers in this article contribute to the organizational culture dis- course by including organizational citizenship behavior as a predictor of organizational culture.

In South Africa, Martins (1989) is a prominent scholar in the field of organizational culture. He used Schein's organizational culture dimension to create an organizational culture framework. E. Martins and N. Martins (2003) define organizational culture as "a system of shared meaning held by members, distinguishing the organization from other organizations". Martins' framework has employee needs and objectives and interpersonal relationships as individual factors, and leadership and management processes as organizational factors (Tuan \& Venkatesh, 2010). However, Martins' framework does not have organizational citizenship behavior as a variable predicting organizational culture.

The unintended consequences of a hostile culture in SOEs in South Africa ultimately compromise parastatals' performance (Mekwe, 2015). It has been found that, in SOEs where the organizational cul- 
ture is hostile, there is a great deal of politics (Mbele, 2015), jealousy (Barlow, 2016), and negative emotions (Phale, 2008), there is high attrition of skilled workers, and junior employees are sexually harassed (Merkin, 2008) and bullied by managers or supervisors (Fapohunda, 2013). Bullying managers are protected by top managers and are not disciplined (Killoren, 2014). Eventually, employees end up not coming to work, taking leave regularly, or both (Magee, Gordon, Robinson, Caputi, \& Oades, 2017), and the SOE struggles to achieve its strategic objectives or goals (Wiedmer, 2011). Sometimes bullying is not vertical but is horizontally perpetrated by employees who have a close relationship with bellicose managers (Katrinli, Atabay, Gunay, \& Cangarli, 2010). On the other hand, it had been found that SOEs with a culture of respect and unity have the potential to realize their expected outcomes like, amongst others, delivering services to the public (Mahlangu, 2001).

Previous research has shown that, when the culture is hostile, employees do not come to work (Magee et al., 2017; Sarafraz \& Kia, 2015), and they only do their jobs and do not work beyond the call of duty (Garg \& Ramjee, 2013), managers abuse the performance appraisal (Idowu, 2017; Cappelli \& Conyon, 2017) and do address employees' complaints on expeditiously (OECD, 2014). Allen, Barnard, Rush, and Russell (2000) found that ratings consisted of non-prescribed behaviors, rendering the rating employee to attach his/her personal views on what constitutes organizational citizenship behavior. Thus, high-performing employees rated the relationship between organizational citizenship behavior and performance higher than managers (Turnipseed \& Rassuli, 2005).

Mitonga-Monga, Flotman, and Cilliers (2016) revealed a significant positive relationship between organizational citizenship behavior and job satisfaction. Berber and Rofcanin (2012) and Kaur (2013) define organizational citizenship behavior as going beyond call of duty, being present at the workplace, and not abusing leave. In a recent study by Zeyada (2018), organizational culture proved to predict organizational citizenship behavior. However, in a study conducted in India, organizational culture did not predict organizational citizenship behavior (Jain, 2015). In another study, organizational citizenship behavior and organization culture were found to contribute to increasing turnover intentions (Jacobs \& Roodt, 2008). It is hypothesized that:

H1: There is a positive relationship between organizational citizenship behavior and organizational culture.

In order for mediation to take place, Leech, Barrett, and Morgan (2015) argue that these conditions should be met:

1) the independent variable must significantly predict the dependent variable;

2) the independent variable must significantly predict the mediating variable; and

3) the mediating variable must significantly predict the dependent variable.

In this study, the mediating variable was job satisfaction, which is an affective stage of workers that is influenced by the relationship between workers and their supervisors (Baeza, Gonzalez, \& Wang, 2018), as well as how management handles employee complaints or needs (Van Schalkwyk \& Rothmann, 2010) and salaries (Mutsonziwa \& Serumaga-Zakhe, 2015). Based on the previous studies, it can be argued that organizational citizenship behavior has not been tested as a predictor of organizational culture. The following hypotheses $(\mathrm{H})$ were proposed:

H2: There is a positive relationship between organizational citizenship behavior and job satisfaction.

H3: There is a positive relationship between job satisfaction and organizational culture.

In the next section, the study methodology is discussed.

\section{METHODOLOGY}

\subsection{Participants and setting}

The research design was cross-sectional, and respondents were selected using a stratified sampling technique. Respondents were stratified by gender. 
Data were collected from March to April 2018. 800 employees were working at the SOE, and using the formula $n=Z_{1-\alpha / 2}^{2} \cdot P(1-P) / d^{2}$, the sample was 204. Out of 204 respondents, 125 (61.27\%) were male and 79 (38.73\%) were female. The majority of the respondents $(127 ; 62.25 \%)$ were aged between 18 and 35 years. The data revealed that $178(87.25 \%)$ of the respondents were not appointed in management positions and $173(84.80 \%)$ had five or more years' experience at the SOE.

\subsection{Measuring instrument}

Five recruitment and selection items and five organizational culture items (three positive and two bellicose) were taken from Maleka (2012). Some of the sample items were: "Organizational politics are rife in the workplace" and "The culture of hostility is rife in the organization." Five organizational citizenship behavior items were taken from Williams and Anderson's (1991, p. 607) scale. Some of the sample items were: "I volunteer to do things I am not required to do" and "My attendance at work is above the norm." Five job satisfaction items were taken from Spector's (1985, p. 713) scale. Some of the sample items were: "My supervisor provides justification for my performance appraisal score" and "My manager attends to my complaints speedily." Similar to Reis et al.'s (2015, p. 1096) organizational culture study and Armstrong's (2015, p. 811) employee attitude studies (i.e., job satisfaction), respondents rated items on a four-point Likert scale, where 1 was strongly agree and 4 was strongly disagree.

\subsection{Research procedure}

The researchers were given ethical clearance by the university before data collection, after which one researcher went to the SOE to collect the data. Respondents were informed that their participation was voluntary and not coerced to participate in the study. The respondents were informed about the benefits of participating, and confidentiality and anonymity were assured by not asking respondents to write their names on the completed questionnaires. Each respondent was given an informed consent form to complete before completing the questionnaire.

\subsection{Statistical analysis}

The measuring instrument items were subjected to principal component analysis using Statistical Package for Social Sciences (SPSS) version 25. As suggested by Pallant (2016), Pearson's correlation was calculated to determine multicollinearity and the level of significance was 0.05 . Based on Maree's (2016) and Pallant's (2016) recommendation, exploratory factor analysis was used to extract factors and to achieve construct validity. Hayes' process was conducted to determine mediation, and as suggested by Hayes (2014) and Field (2018), bootstrap samples were set to 5,000 .

According to Hayes (2014), the equation for mediation analysis is as follows:

$$
Y=\text { intercept }+c^{\prime} X+b \cdot M+e,
$$

where $Y=$ Outcome variables (organizational culture); Predictor (organizational citizenship behavior); $c^{\prime}=$ regression coefficient of the direct effect of $X$ on $Y$ when $M$ is added to the model; $M=$ mediator (job satisfaction); $b=$ regression coefficient of the indirect effect of $M$ on $Y ; e=$ error term.

\subsection{Validity and reliability}

The researchers followed Christensen, Johnson, and Turner (2015), Babbie (2013) and Kumar (2014), advice and achieved content validity by presenting the measuring instrument to an expert to validate the items. Before data collection, the measuring instrument was pre-tested on 10 respondents. Before principal component analysis, the suitability of the data for factor analysis was assessed. The KaiserMeyer-Olkin value was 0.70 , which was above the value of 0.5 recommended by Hair, Black, Babin, and Anderson (2014). Bartlett's test of sphericity was statistically significant at $p=0.00$. Principal component analysis revealed three factors with eigenvalues exceeding 1 , explaining a total variance of $59.80 \%$. As suggested by Hair, Black, Babin, and Anderson (2014), a cut-off of 0.3 was used in this study as inclusion criterion for factor loadings in the model. Three factors emerged after conducting factor analysis. The first factor, labeled as job satisfaction, had five items with factor loadings ranging from 0.57 to 0.82 . The second factor, labeled as organizational citizenship behavior, had 
three items with factor loadings ranging from 0.76 to 0.81 . The third factor, labeled as organizational culture, had two bellicose items with factor loadings of 0.838 and 0.842 .

The Cronbach's alphas for the organizational psychology scales were as follows: 0.76 for job satisfaction, 0.69 for organizational citizenship behavior, and 0.62 for organizational culture. It is argued that all organizational psychology scales were reliable because they were within the Cronbach's alpha range of 0.6 to 0.9 , as suggested by Maree (2016).

\section{RESULTS}

Table 1 presents the descriptive statistics. The data showed that the respondents agreed with organizational culture $(M=2.00, S D=0.77)$ and organizational citizenship items $(M=2.00, S D=0.69)$. On the other hand, the data showed that the respondents disagreed with job satisfaction $(M=3.00, \quad S D=0.65)$ and recruitment and selection $(M=3.00, S D=0.83)$ items.

Before calculating mediation, certain assumptions were checked, and the data on histogram showed a bell shape. The line on the P-P plot points was on the diagonal "from bottom left to right", and the correlations between the independent variables (i.e., job satisfaction and organizational cit- izenship behavior) were above 0.7. None of the variance inflation factors were above 10 , and the tolerance was less than 0.10 (Pallant, 2016). These data suggested that the assumptions of normality, linearity, and multicollinearity were not violated (Tabachnick \& Fiddel, 2014).

Table 2 presents the mediation results. The data showed that the first path, known as $a$, had an $R$-squared of 0.01 , while $\mathrm{F}(1,197)=1.23$ and $p=0.27$. It can be interpreted that organizational citizenship behavior explained $1 \%$ of total variance of job satisfaction. $H 1$ was supported because the organizational citizenship behavior significantly predicted organizational culture ( $\beta=0.19, p=0.02)$. H2 was not supported as it could be observed that organizational citizenship behavior did not significantly predict job satisfaction $(\beta=0.07, p=0.28)$. $H 3$ was not supported because job satisfaction was not a significant predictor of organizational culture $(\beta=0.05, p=0.55)$. When job satisfaction and organizational citizenship behavior were predictors of organizational culture, the $R$-squared was $0.03, \mathrm{~F}(2,196)=3.39$ and $p=0.04$, meaning that the combination of job satisfaction and organizational citizenship behavior explained 3\% of total variance of organizational culture. The data also showed that the confidence interval included zero $(-0.01,0.27)$, suggesting that mediation did not take place.

Table 1. Mean, standard deviation, and correlation

\begin{tabular}{|c|c|c|c|c|c|}
\hline Variable & Mean & $\begin{array}{l}\text { Standard } \\
\text { deviation }\end{array}$ & $\begin{array}{c}\text { Organizational } \\
\text { culture }\end{array}$ & $\begin{array}{c}\text { Job } \\
\text { satisfaction }\end{array}$ & $\begin{array}{c}\text { Organizational citizenship } \\
\text { behavior }\end{array}$ \\
\hline Organizational culture & 2.00 & 0.77 & 1 & - & - \\
\hline Job satisfaction & 3.00 & 0.65 & 0.06 & 1 & - \\
\hline Organizational citizenship behavior & 2.00 & 0.69 & $0.18^{*}$ & 0.07 & 1 \\
\hline
\end{tabular}

Note: * Correlation is significant at the 0.05 level (2-tailed).

Table 2. The data showing paths and constant

\begin{tabular}{|c|c|c|c|c|c|c|c|c|}
\hline \multicolumn{5}{|c|}{$\mathrm{M}(\mathrm{JS})$} & \multicolumn{4}{|c|}{$Y(O C)$} \\
\hline Antecedent & $\begin{array}{l}\text { Path and } \\
\text { constant }\end{array}$ & Coefficient & $\begin{array}{c}\text { Standard } \\
\text { error }\end{array}$ & p & $\begin{array}{l}\text { Path and } \\
\text { constant }\end{array}$ & Coefficient & SE & $\mathbf{p}$ \\
\hline$X(\mathrm{OCB})$ & $a$ & 0.07 & 0.07 & 0.28 & $c^{\prime}$ & 0.19 & 0.08 & 0.19 \\
\hline$M(J S)$ & - & - & - & - & b & 0.05 & 0.08 & 0.55 \\
\hline Constant & i & 2.50 & 0.14 & 0.07 & $\mathrm{i}$ & 1.89 & 0.27 & 0.00 \\
\hline \multicolumn{5}{|c|}{$R^{2}=0.01$} & \multicolumn{4}{|l|}{$R^{2}=0.03$} \\
\hline \multicolumn{5}{|c|}{$F(1,197)=1.23, p=0.27$} & \multicolumn{4}{|c|}{$F(2,196)=3.39, p=0.04$} \\
\hline
\end{tabular}

Note: $\mathrm{OCB}=$ organizational citizenship behavior, $\mathrm{OC}=$ organizational culture, $\mathrm{JS}=$ job satisfaction. $a, b$ and $c^{\prime}$ are paths on the model, and $i$ is the constant. 


\section{DISCUSSION}

One of the first specific objectives was to determine how the respondents rated organizational culture and its predictors. The mean score of the organizational culture items $(M=2.00, S D=0.69)$ showed a negative trend, suggesting that respondents agreed that organizational politics and culture of hostility were rife at the SOE. These data were consistent with the study conducted by Maleka and Rankhumise (2014) at another parastatal. The unintended consequences of workplace politics are that employees who do not have the right skills are appointed into managerial positions. Since they do not have managerial competencies, they cannot help the SOE achieve its objectives, and they have adversarial relationships with subordinates (Maleka, 2012). Drucker (as cited in Teasdale, 2002, p. 195) opines that "culture eats strategy for breakfast". Previous research has shown that, when the culture is hostile, employees do not come to work (Magee et al., 2017; Sarafraz \& Kia, 2015), and they only do their jobs and do not work beyond the call of duty (Garg \& Ramjee, 2013). When such a culture is rife, there are no mentoring, coaching, and development opportunities, as found by Booysen (2007). To reverse these trends, managers at SOEs should foster a culture of respect that rewards and recognizes employees who go beyond call of duty (Berber \& Rofcanin, 2012; Kaur, 2013; Mahlangu, 2001; Spector, 1985). Furthermore, Van Rooij and Fine (2018) posit that a positive culture that promotes transparency, honesty, and responsibility should be inculcated or fostered by managers. Research has found that managers who changed a negative culture to one of respect and inspiration were supported by their subordinates to achieve strategic goals (Phale, 2008).

Similar to organizational culture, the mean score for organizational citizenship behavior was $(M=2.00 ; S D=0.69)$. This suggested that respondents agreed with these statements. The present study results showed that employees rated organizational citizenship behavior positively when responding to the statements: "I volunteer to do things I am not required to do" and "My attendance at work is above the norm." Bachrach, Powell, Bendoly, and Richey (2005, p. 14) found that when employees exhibited organizational citizenship behavior, they worked independently and per- formed their tasks with aplomb. Such employees did not abuse leave (Magee et al., 2017) and did not resign (Ibukunoluwa, Anuoluwapo, \& Agbude, 2015; Karam, Kuo, \& Towson, 2008; Wong, 2017).

It was found that respondents rated job satisfaction items negatively $(M=3.00, S D=0.65)$. It can be claimed that respondents disagreed with statements such as: "My supervisor reviews my performance with me" and "My immediate supervisor articulates a compelling vision of the future." Previous research at another South African SOE showed that managers who were insecure and did not like to be challenged gave employees low performance scores (Maleka, 2012). Cappelli and Conyon (2017) and Idowu (2017) found that supervisors who justified performance appraisal scores enhanced employee satisfaction levels. The results were not consistent with research by the OECD (2014), which found that when supervisors resolved employees' complaints in the parastatal, employees were satisfied.

To test mediation or indirect effects, the Hayes' (2014) analysis was used. The results showed a positive relationship between organizational citizenship behavior and job satisfaction, but the relationship was not significant $(\beta=0.07, p=0.28)$. Similarly, Mitonga-Monga, Flotman, and Cilliers (2016) found a significant positive relationship between organizational citizenship behavior and job satisfaction. In SOEs where such relationships are significant, the organizations perform and reach their strategic objectives (Wiedmer, 2011).

The indirect relationship between job satisfaction and organizational culture was also tested. It was also found that job satisfaction did not significantly predict organizational culture $(\beta=0.05$, $p=0.55$ ), but the relationship was positive. Toumivaara (2015) also found a positive relationship between job satisfaction and organizational culture. Based on the results of the indirect effect, it can be concluded mediation did not take place. Since organizational citizenship behaviors and job satisfaction only contributed $3 \%$ of hostile organization culture, it means $97 \%$ of other factors not measured in this study might contribute to a hostile culture. Research in the SOE established that the other drivers of a bellicose culture are a patronage relationship, abuse and ostracizing dili- 
gent and hardworking employees (Wiedmer, 2011), micro-management (Dwivedi, Kaushik, \& Luxmi, 2014) corruption, and undesirable treatment of employees (Thomas, 2012).

Lastly, a direct, significant, and positive relationship between organizational citizenship behavior and organizational culture $(\beta=0.19, p=0.02)$ was established in this study. This finding was surprising since the SOE's organizational culture was deemed bellicose, but the organizational citizenship behavior items (i.e., coming to work and volunteering to do things not required to do) were positive. Previous research has shown that, when the culture is hostile, employees do not come to work (Magee et al., 2017; Sarafraz \& Kia, 2015), and they only do their jobs and do not work beyond the call of duty (Garg \& Ramjee, 2013). However, the findings agreed with the study conducted by Allen, Barnard, Rush, and Russell (2000) and Saks and Gruman (2011) who found that SOE employees went beyond call of duty because the culture was not hostile, but it was based on principles of respect and dignity.

\section{CONCLUSION}

The main purpose of the study was to explore organizational culture at the SOE. Notwithstanding the limitations of this exploratory study on two predictors of organizational culture, the study has contributed by indicating that organizational citizenship behavior is a predictor of organizational culture, where such a relationship has not been fully established in the literature in the South African context. Additionally, the study has contributed by finding that, even though the SOE's organizational culture was predominantly bellicose, employees volunteered to go beyond call of duty, and workplace attendance was above the norm.

It can be concluded that a bellicose culture could be changed to a positive culture if SOE's managers:

- created campaigns that will foster a culture of respect instead of a bellicose culture (i.e., hostility and politics);

- continued encouraging and motivating employees to go beyond call of duty and not abuse the leave system; and

- maintained a culture of conducting performance appraisals fairly and resolving employees' complaints speedily.

Unlike in this study, future researchers should have five respect and bellicose items, so that, when factors analysis is conducted, the two cultures are unidimensional and distinct. In the future, a similar study should be conducted in other business units and SOEs, using larger representative samples. It is recommended that in the future, research should focus on engagement as a mediator, and remuneration and gender as predictors of job satisfaction. Previous SOE research has found that, in bellicose cultures, gender pay disparities are immense (Maleka, 2012).

The limitations of the study were, firstly, that the study was conducted at only two business units of the organization in one province. Secondly, the study was based on a cross-sectional design, which gave a once-off snapshot picture of organizational culture at the SOE.

Despite these limitations, this study contributed to the body of knowledge in that it is one of the few that were conducted at a South African SOE that explored whether job satisfaction mediated the relationship between organizational citizenship behavior and organizational culture. This study contributes to the body of knowledge by establishing a predictive path between organizational citizenship behavior and organizational culture, which, according to the literature, is under-researched in the South African 
context. Although some of the study paths were not significant (refer to Table 2), this exploratory study created a framework that managers can use to change a bellicose culture into a positive one. The study used valid and reliable scales.

\section{REFERENCES}

1. Allen, T. D., Barnard, S., Rush, M. C., \& Russell, J. E. A. (2000). Ratings of organizational citizenship behavior: Does the source make a difference? Human Resource Management Review, 10(1), 97-114. https://doi. org/10.1016/S1053-4822(99)000418

2. Ankrah, N. A., Proverbs, D., \& Debrah, Y. (2009). Factors influencing the culture of a construction project organization: An empirical investigation. Engineering and Architectural Management, 16(1), 26-47. https://doi. org/10.1108/09699980910927877

3. Armstrong, C. (2015). Workplace motivation and its impact on job satisfaction and self-esteem. Retrieved from http://hdl.handle. net/10788/2786

4. Babbie, E. (2013). The practice of social research (13th ed.). Belmont, CA: Wadsworth

5. Bachrach, D. G., Powell, B. C., Bendoly, E., \& Richey, R. G. (2006). Organizational citizenship behavior and performance evaluations: exploring the impact of task interdependence. Journal of Applied Psychology, 91(1), 193-201. https:// doi.org/10.1037/0021-9010.91.1.193

6. Baeza, M. A., Gonzalez, J. A., \& Wang, Y. (2018). Job flexibility and job satisfaction among Mexican professionals: A socio-cultural explanation. Employee Relations, 40(5), 921-942. https://doi. org/10.1108/ER-12-2016-0236

7. Barlow, A. (2016). SOE failure: A symptom? The Journal of the Helen Suzman Foundation, 78, 55-63. Retrieved from https://hsf.org.za/ publications/focus/focus-78-theeconomy-1/andrew-barlow.pdf

8. Berber, A., \& Rofcanin, Y. (2012). Investigation of organization citizenship behavior construct: A framework for antecedents and consequences. International Journal of Social Research, 2(4), 195-210. Retrieved from https://www.semanticscholar.org/paper/Investigationof-Organization-Citizenship-Behavior-Berber-Rofcanin/7bf1202bc20c5 e6a31c4566b4e4e8ba181012509

9. Booysen, L. (2007). Barriers to employment equity and implementation and retention of black management in South Africa. South African Journal of Labor Relations, 31(4), 47-71. Retrieved from https://www.researchgate.net/ publication/265225634_Barriers_to_ employment_equity_implementation_and_retention_of_blacks_in_ management_in_South_Africa

10. Cappelli, P., \& Conyon, M. J. (2017). What do performance appraisals do? ILR Review, 71(1), 88-116. https://doi. org/10.1177/0019793917698649

11. Chavunduka, D., Fauzi, R., Muranda, Z., Sifile, O., Mabvure, T. J., \& Dandira, M. (2014). Antecedents of effective management of public enterprise restructuring in Zimbabwe: An organizational culture perspective. The International Journal of Business and Management, 2(10), 105-113. Retrieved from https:// www.academia.edu/12310076/ Antecedents_for_Effective_Management_of_Public_Enterprise_Restructuring_in_Zimbabwe_An_Organizational_Culture_Perspective

12. Christensen, L. B., Johnson, R. B., \& Turner, L. A. (2015). Research methods, design and analysis. Boston, MA: Pearson.

13. Confeld, S. (2016). The importance of positive school culture (A Master's Project). Retrieved from https://alfredadler.edu/library/masters/2016/ sara-confeld

14. Demir, K. (2015). The effects of organizational trust on the culture of teacher leadership in primary schools. Educational Sciences:
Theory and Practice, 15(3), 621634. https://doi.org/10.12738/ estp.2015.3.2337

15. Dwivedi, S., Kaushik, S., \& Luxmi, M. (2014). Impact of organizational culture on commitment of employees: an empirical study of BPO sector.in India. VIKALPA: The Journal for Decision Makers, 39(3), 77-92. https://doi. org/10.1177/0256090920140306

16. Fapohunda, T. M. (2013). Managing workplace bullying. Journal of Human Resources Management, 1(3), 39-47. https://doi.org/10.11648/j. jhrm.20130103.11

17. Field, A. (2018). Discovering statistics using IBM statistics (5th ed.). Thousand Oaks, CA: SAGE.

18. Fleury, M. T. L. (2009). Organizational culture and renewal of competences. BAR - Brazilian Administration Review, 6(1), 1-14. https://doi.org/10.1590/S180776922009000100002

19. Garg, A. K., \& Ramjee, D. (2013). The relationship between leadership styles and employee commitment at a parastatal company in South Africa. International Business and Economics Research, 12(11), 14111436. https://doi.org/10.19030/iber. v12i11.8180

20. Hair, F. H., Black, W. C., Babin, B. J., \& Anderson, R. E. (2014). Multivariate data analysis. Harlow: Pearson.

21. Harrison, R. (1972). Understanding your organization's character. Harvard Business Review, 50(1), 119-128.

22. Hayes, A. F. (2013). Introduction to mediation, moderation and conditional process analysis. New York: Guilford.

23. Ibukunoluva, O. E., Anuoluwapo, A. G., \& Agbude, G. A. (2015). Benefits of organizational citizenship behavior for individual employees. 
Covenant International Journal of Psychology (CIJP), 1(1), 50-69. Retrieved from https://journals. covenantuniversity.edu.ng/index. php/cijp/article/view/183/178

24. Jacobs, E., \& Roodt, G. (2008). Organizational culture of hospitals to predict turnover intentions of professional nurses. Health $S A$ Gesondheid, 13(1), 258. https://doi. org/10.4102/hsag.v13i1.258

25. Jain, A. K. (2015). Volunteerism and organizational culture: Relationship to organizational commitment and citizenship behaviors in India. Cross-Cultural Management, 22(1), 116-144. https://doi.org/10.1108/ CCM-11-2013-0167

26. Kamaamia, A. T. (2017). The effect of organizational culture on organizational performance: $A$ case of Kenya School of Monetary Studies (Ksms) (Master's Thesis). Retrieved from http://erepo.usiu. ac.ke/11732/3134

27. Katrinli, A., Atabay, G., Gunay, G., \& Cangarli, B. G. (2010). Nurses' perceptions of individual and organizational political reasons for horizontal peer bullying. Nursing Ethics, 17(5), 614-627. https://doi. org/10.1177/0969733010368748

28. Kaur, S. P. (2013). Variables in research. Indian Journal of Research and Reports in Medical Sciences, 3(4), 36-38. Retrieved from https://sites usp.br/dncc/wp-content/uploads/ sites/598/2019/09/complementoaula-1.pdf

29. Killoren, R. (2014). The toll of workplace bullying. Research Management Review, 20(1), 1-13. Retrieved from https://www.academia.edu/8587059/The_Toll_of_ Workplace_Bullying

30. Kumar, R. (2014). Research methodology: A step by step guide for beginners (4th ed.). London: Sage.

31. Kwantes, C. T., Karam, C. M., Kuo, B. C. M., \& Towson, T. (2008). Culture's influence on the perception of organizational citizenship behavior as in-role or extra-role. International Journal of Intercultural Relations, 32(3), 229-243. https://doi.org/10.1016/j. ijintrel.2008.01.007

32. Leech, N. C., Barrett, K. C., \& Morgan, G. A. (2015). SPSS for intermediate statistics: Use and interpretation (5th ed.). New York: Rouledge.

33. Luu, T., \& Venkatesh, S (2010). Organizational culture technological innovation adoption in private hospitals. International Business Research, 3(3), 144153. Retrieved from https://doi. org/10.5539/ibr.v3n3p144

34. Magee, C., Gordon, R., Robinson, L., Caputi, P., \& Oades, L.

(2017). Workplace bullying and absenteeism: The mediating roles of poor health and work engagement. Human Resource Management Journal, 27(3), 319-334. https://doi. org/10.1111/1748-8583.12156

35. Mahlangu, B. B. M. (2001). Public accountability and transparency of parastatal organizations in South Africa (Master's Thesis). Retrieved from http://hdl.handle. net/10413/3246

36. Maleka, M. J. (2012). An indepth investigation of factors that contributing to employee dissatisfaction at a Business Application Solution Centre (BASC), Eskom (Doctoral Thesis). Unisa. Retrieved from https://pdfs.semanticscholar.org/bbe4/0a183d1dddf04 1411c4f90a366b91bac2068.pdf

37. Maleka, M. J., \& Rankhumise, E. M. (2014). The impact of management practices on job satisfaction: Insights from a state-owned institution. Problems and Perspectives in Management, 12(4), 476-484. Retrieved from https://businessperspectives.org/ component/zoo/the-impact-ofmanagement-practices-on-jobsatisfaction-insights-from-a-stateowned-institution

38. Maree, K. (Ed.). (2016). First steps in research (2nd ed.). Pretoria: Van Schaik.

39. Martins, E., \& Martins, N. (2003). Organizational culture in organizational behavior: Global and South African perspectives. Cape Town: Pearson.

40. Martins, N. (1989). Organizational culture in a financial institution (Ph.D. Thesis). University of South Africa, Pretoria.

41. Mbele, N. O. (2015). Corporate governance in state-owned enterprises (Doctoral Thesis). Retrieved from https://hdl.handle. net/10539/21130

42. Mekwe, L. P. (2015). A critical review of corporate governance reforms relating to South African state-owned enterprises. Retrieved from http:// hdl.handle.net/11394/5171

43. Merkin, R. S. (2008). The impact of sexual harassment on turnover intentions, absenteeism, and job satisfaction: Findings from Argentina, Brazil and China. Journal of International Women Studies, 10(2), 73-91. Retrieved from https:// vc.bridgew.edu/jiws/vol10/iss2/7

44. Mitonga-Monga, J., Flotman, A., \& Cilliers, F. (2016). The relationship between job satisfaction and organizational citizenship behaviour: A Democratic Republic of Congo organizational perspective. Journal of Contemporary Management, 13(1), 1064-1084. Retrieved from https://journals.co.za/content/jcman/13/1/ EJC197524

45. Mutsonziwa, K., \& SerumagaZakhe, P. (2015). Exploring employee satisfaction and leadership attributes within the research industries in Gauteng Province. Journal of Contemporary Management, 12(1), 164-183. Retrieved from https://journals.co.za/content/jcman/12/1/ EJC169979

46. Naidoo, P., \& Martins, N. (2014). Investigating the relationship between organizational culture and work engagement. Problems and Perspectives in Management, 12(4), 432-440. Retrieved from https:// businessperspectives.org/component/zoo/investigating-the-relationship-between-organizationalculture-and-work-engagement

47. O’Donnell, O., \& Boyle, R. (2008). Understanding and managing organizational culture (CPMR Discussion Paper No. 40). Retrieved from https://www. ipa.ie/_fileUpload/Documents/ CPMR_DP_40_Understanding Managing_Org_Culture.pdf

48. OECD. (2014). Guidelines on the Governance of State-Owned Enterprises for Southern Africa. Retrieved from https://www. 
oecd.org/daf/ca/SOE-GuidelinesSouthern-Africa.pdf

49. Pallant, J. (2016). SPSS survival manual (6th ed.). Maidenhead: McGraw-Hill.

50. Phale, M. M. (2008). Work-related well-being of enterprises in a South African parastatal (Ph.D. Thesis). Retrieved from http://hdl.handle. net/10394/4122

51. Raaphorst, N. (2017). Uncertainty in bureaucracy (Doctoral Dissertation). Retrieved from https://repub.eur.nl/pub/102300/ Doctoral-dissertation-NadineRaaphorst.pdf

52. Ramdhan, A., Ramdhan, $M$. A., \& Ainisyifa, H. (2017). Model conceptual framework of corporate culture on employee commitment to organization. International Business Management, 11(3), 826-830. https://doi.org/10.36478/ ibm.2017.826.830

53. Reis, G., Trullen, J., \& Story, J. (2015). Perceived organizational culture and engagement: The mediating role of authenticity. Journal of Managerial Psychology, 31(6), 1091-1105. https://doi. org/10.1108/JMP-05-2015-0178

54. Rovithis, M., Liardakis, M. Merkouris, A., Patiraki, E., Nassilaki, M., \& Philithis, A. (2017). Organizational culture among levels of health care services in Crete (Greece). Applied Nursing Research, 36, 9-18. https:// doi.org/10.1016/j.apnr.2017.05.003

55. Saha, S., \& Kumar, S. P. (2018). Organizational culture as a moderator between affective commitment and job satisfaction: Empirical evidence from Indian public sector enterprises. International Journal of Public Sector Management, 31(2), 184-206. https://doi org/10.1108/IJPSM-03-2017-0078

56. Saks, A. M., \& Gruman, M. (2011). Manage employee engagement to manage performance. Industrial and Organizational Psychology, 4(2), 204-207. https://doi.org/10.1111/j.17549434.2011.01328.x
57. Sarafraz, S. A., \& Kia, A. R. (2015). Examining the relationship between organizational culture and organizational citizenship behavior in the social security branches of Khorramabad. MAGNT Research Report, 3(1), 368-376.

58. Sharma, N. P., Sharma, T., \& Agarwal, M. N. (2015). Measuring employee perception of performance management systems effectiveness. Employee Relations, 38(2), 224-247. https:// doi.org/10.1108/ER-01-2015-0006

59. Spector, P. (1985). Measurement of human service staff satisfaction: Development of the Job Satisfaction Survey. American Journal of Community Psychology, 13(6), 693-713. https://doi. org/10.1007/BF00929796

60. Tabachnick, B. G., \& Fiddel, L. S. (2014). Using multivariate statistics (6th ed.). Harlow: Pearson. Retrieved from https://www.pearson.com/us/higher-education/ program/Tabachnick-Using-Multivariate-Statistics-6th-Edition/ PGM332849.html

61. Teasdale, S. (2002). Culture eats strategy for breakfast! Informatics in Primary Care, 10, 195-196. https://doi.org/10.14236/jhi. v10i4.259

62. Thomas, A. (2012). Governance at South African state-owned enterprises: what do annual report and the print media tell us? Social Responsibility Journal, 8(4), 448-470. https://doi. org/10.1108/17471111211272057

63. Tseng, S. (2017). Investigating the moderating effects of organizational culture and leadership style on IT-adoption and knowledge-sharing intention. Journal of Enterprise Information Management, 30(4), 583-604. https://doi.org/10.1108/JEIM-042016-0081

64. Turnipseed, D. L., \& Rassuli, A. (2005). Performance perceptions of organizational citizenship behaviour at work: a bi-level study among managers and employees. British Journal of Management, 16(3), 231-244. https://doi.org/10.1111/j.14678551.2005.00456.x
65. Van Rooij, B., \& Fine, A. (2018). Toxic corporate culture: assessing organizational processes of deviancy. Administrative Sciences, 8(3), 1-38. https://doi.org/10.3390/ admsci8030023

66. Van Schalkwyk, L., \& Rothmann, S. (2010). Job satisfaction in a chemical factory. Southern African Business Review, 14(3), 108-130. Retrieved from https://pdfs.semanticscholar.org/6dfb/b3a7d1bd4b398f4974e00e72687fff823b50. pdf

67. Vesala, H., \& Toumivaara, H. V. S. (2015). Slowing work down teleworking in rural settings? Personnel Review, 44(4), 511-528. https://doi.org/10.1108/PR-072013-0116

68. Wiedmer, T. L. (2011). Workplace bullying: Costly and preventable. Morality in Education, 77(2), 3542. Retrieved from https://www. homeworkforyou.com/static_media/uploadedfiles/Workplace $\% 20$ bullying\%20Article.pdf

69. Williams, L. J., \& Anderson, S. E. (1991). Job satisfaction and organizational commitment as predictors of organizational citizenship behavior and in-role behaviors. Journal of Management, 17(3), 601-617. https://doi. org/10.1177/014920639101700305

70. Wong, Y. (2017). Affective commitment, loyalty to supervisor and guanxi: Chinese employees in joint ventures and reformed state-owned enterprises. Journal of Chinese Human Resource Management, 8(2), 77-93. https://doi.org/10.1108/ JCHRM-04-2017-0007

71. Zeyada, M. (2018). Organizational culture and its impact on organizational citizenship behavior. International Journal of Academic Research in Business and Social Sciences, 8(3), 418-429. Retrieved from https://doi.org/10.6007/ IJARBSS/v8-i3/3939 